Article

\title{
Age-Stage, Two-Sex Life Tables of the Predatory Mite Cheyletus Malaccensis Oudemans at Different Temperatures
}

\author{
Weiwei Sun, Miao Cui, Liyuan Xia, Qing Yu, Yang Cao and Yi Wu * \\ Academy of National Food and Strategic Reserves Administration, National Engineering Laboratory of Grain \\ Storage and Logistics, Henan Collaborative Innovation Center of Grain Crops, Jiangsu Collaborative Innovation \\ Center for Modern Grain Circulation and Safety, No. 11 Baiwanzhuang Street, Beijing, 100037, China; \\ sww@chinagrain.org (W.S.); cm@chinagrain.org (M.C.); xly@chinagrain.org (L.X.); yuq@chinagrain.org (Q.Y.); \\ cy@chinagrain.org (Y.C.) \\ * Correspondence: wuyi@chinagrain.org; Tel.: +86-10-8190-2316; Fax: +86-10-8190-2490
}

Received: 12 January 2020; Accepted: 6 March 2020; Published: 12 March 2020

\begin{abstract}
Cheyletus malaccensis Oudemans is a predatory mite inhabiting grain depots in China. The relationship between temperature and the population growth rate of $C$. malaccensis is useful for predicting its population dynamics. Age-stage, two-sex life tables of the predator, C. malaccensis, reared on Acarus siro were constructed under laboratory conditions at 22, 24, 28, 30, and $32{ }^{\circ} \mathrm{C}$, $75 \%$ relative humidity, and a 0:24 h (L:D) photoperiod. Increasing temperature shortened the development time of the immature stages. The complete generation time of $C$. malaccensis ranged from $11.10 \mathrm{~d}$ to $27.50 \mathrm{~d}$. Life table parameters showed that $28^{\circ} \mathrm{C}$ was the optimum temperature for the growth and development of $C$. malaccensis; populations could increase rapidly at this temperature. The highest net reproductive rate $\left(R_{0}=290.25\right)$ and highest fecundity $(544.52)$ occurred at $28^{\circ} \mathrm{C}$. Temperature significantly affected the intrinsic rate of increase $(\mathrm{r})$, fecundity, and finite rate of increase

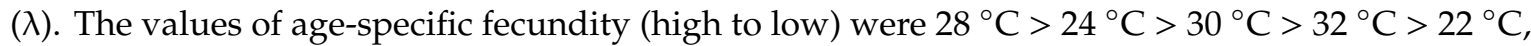
while the values of age-stage-specific fecundity had the same trend.
\end{abstract}

Keywords: Cheyletus malaccensis Oudemans; biological control; age-stage two-sex life table

\section{Introduction}

Cheyletus malaccensis Oudemans is a predator mite species in China. It preys on acarid grain mites and small arthropods, such as the eggs and first-instar larvae of stored grain pests [1-3]. C. malaccensis populations can be self-sustaining for limited time periods by cannibalism $[4,5]$. C. malaccensis is the dominant predaceous mite species in grain depots [6-10] and provides biological control of common pests in stored grain [11]. C. malaccensis development includes five stages: egg, larvae, protonymph, deutonymph, and adult. The deutonymph is absent in males. Virgin females always produce males, whereas fertilized females produce both male and female progeny $[12,13]$.

Temperature is an important component of predator-prey interactions, as it influences pest and natural enemy population dynamics such as developmental time [14], life span [15], reproductive rate [16], and control efficiency [17-19]. Temperature affects the survival and development of mites [20], and seasonal temperature variations also affect predator-prey interactions [12]. For $C$. malaccensis, the female life span (egg to adult) is longer (20-23 d) than the male life span (15-17 d) at $25^{\circ} \mathrm{C}$ [21]. Palyvos and Emmanouel [12] studied the life history of $C$. malaccensis at six constant temperatures: 17.5, 20, 25, $30,32.5$, and $35^{\circ} \mathrm{C}$. The life span was $53.0 \mathrm{~d}$ at $17.5^{\circ} \mathrm{C}$, and $15.4 \mathrm{~d}$ at $35^{\circ} \mathrm{C}$. Toldi et al. [22] found that fecundity was highest at $25^{\circ} \mathrm{C}$ with the value of $415.62 \pm 24.78 \mathrm{eggs} / \mathrm{female}$, and lowest at $20^{\circ} \mathrm{C}$. Thus, temperature has a significant influence on the development and reproduction of $C$. malaccensis $[14,23]$. 
Life tables can be used for predicting the population levels of pests and predators as well as the efficiency of biological control [24]. Insect-related life table technology is a technical method used to study population dynamics $[16,25,26]$. However, the traditional life table of $C$. malaccensis only addresses the females, while ignoring the males, life stage differentiation, and variable developmental rates. This is a limited practical application of the life table. The age-stage, two-sex life table is a superior alternative since it considers males and different age individuals in the population $[27,28]$ and systematically studies the growth, development, survival rate, reproduction, and pesticide susceptibility of males and females. To quantify the effect of temperature on the development of C. malaccensis, life stages of $C$. malaccensis were held at constant temperatures and the life history raw data were analyzed based on an age-stage, two-sex life table. The age-stage, two-sex life table technology has also been used to predict the population growth and predation rate of other natural enemies [29].

To understand the relationship between temperature and the population growth rate of C. malaccensis, we constructed age-stage, two-sex life tables of C. malaccensis fed on Acarus siro Linnaeus at different temperatures. Specifically, we studied (a) the life history of $C$. malaccensis at $22,24,28,30$, and $32{ }^{\circ} \mathrm{C}$ and $75 \% \mathrm{RH}$, and (b) the influence of temperature on the development and reproduction of $C$. malaccensis. The results provided basic information for biological control programs that use C. malaccensis.

\section{Materials and Methods}

\subsection{Insect Rearing}

C. malaccensis was initially collected from Haikou, Hainan Province, China and reared at the Institute of Grain Storage \& Logistics Academy of National Food and Strategic Reserves Administration at $28^{\circ} \mathrm{C}, 75 \% \mathrm{RH}$, and a photoperiod of 0:24 h(L:D). The mites were identified based on morphological characteristics [1].

Acarus siro was provided by the Crop Research Institute, Prague, Czech Republic and was reared on whole wheat flour, under constant conditions $\left(28^{\circ} \mathrm{C}, 75 \% \mathrm{RH}\right.$, and 0:24 (L:D)).

\subsection{Life Table Study of C. Malaccensis}

Fifty female $C$. malaccensis adults were randomly selected and the mites were reared in plastic micro rearing cells $(20 \times 20 \times 2 \mathrm{~mm})$ at $28^{\circ} \mathrm{C}$ and $75 \% \mathrm{RH}$, with $A$. siro as prey food. In the center of each block, a conical shaped hole was drilled. A piece of black filter paper $(20 \times 20 \mathrm{~mm})$ was attached to the lower surface of the cell and a suitable glass cover slip was placed on its upper surface (Figure 1).

After 24 h, 50 eggs were collected and designated as the F1 generation for further study. To determine the optimum development temperature, experiments were conducted at five temperatures $\left(22,24,28,30\right.$, and $\left.32{ }^{\circ} \mathrm{C}\right)$, with $75 \% \mathrm{RH}$. The $\mathrm{F} 1$ generation eggs from each adult were randomly selected as a cohort to construct the corresponding life table.

Eggs were individually placed inside blocks and subjected to different temperatures $(22,24,28$, 30 , and $32{ }^{\circ} \mathrm{C}$ ) at $75 \% \mathrm{RH}$. A. siro were used as food and 15-25 A. siro were added daily for each C. malaccensis. Each block was checked daily for eggs. The egg incubation period, development times of immature mites, survival rates of larvae and adults, and fecundity of females (number of eggs laid) were recorded daily. 

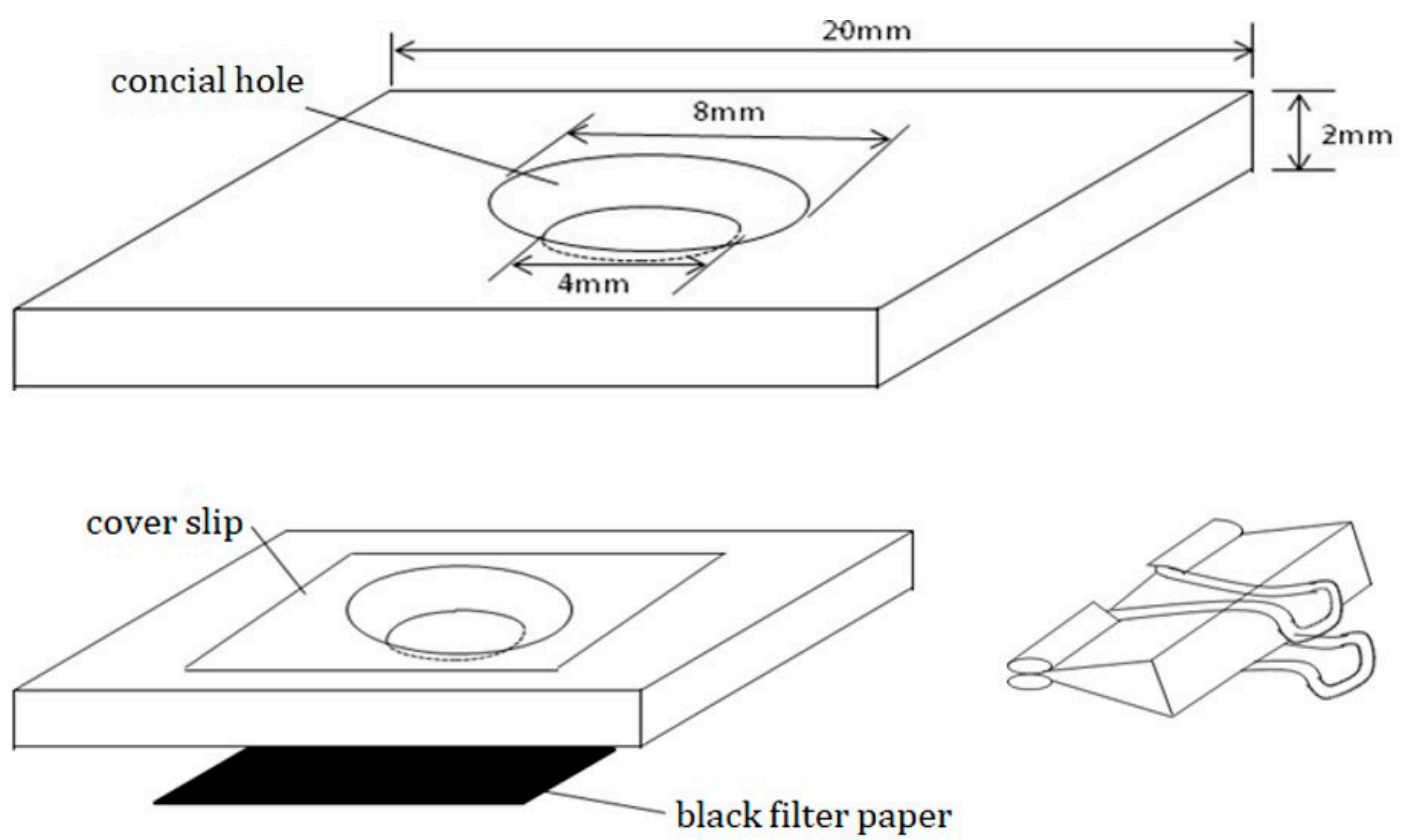

Figure 1. Feeding container and schematic diagram for use.

\subsection{Life Table Analysis}

The raw data for C. malaccensis individuals were analyzed on the basis of the age-stage, two-sex life table theory [27,28] using a TWOSEX-MSChart-2018.11.01 [30] (http://140.120.197.173/Ecology/ prod02.htm).

Because of the absence of male deutonymphs, all nymphal stages were referred to as "nymph". The four stages considered in the growth and development of $C$. malaccensis were egg, larva, nymph, and adult. The age-stage-specific survival rate $\left(S_{x j}\right)$ (probability that a newly laid egg will survive to age $\mathrm{x}$ and stage $\mathrm{j}$ ), the age-stage-specific fecundity $\left(f_{x j}\right)$ (number of hatched eggs produced by female adult at age $x$, and $j$ is the life stage number $(j=4)$, the age-specific survival rate $\left(l_{x}\right)$ (probability that a newly laid egg will survive to age $\mathrm{x}$ ), the age-specific fecundity curve $\left(m_{x}\right)$ (the average fecundity of the individuals), and the age-stage life expectancy $\left(e_{x j}\right)$ (expected time that an individual of age $\mathrm{x}$ and stage $\mathrm{j}$ is expected to live) were calculated as follows [31,32]:

$$
\begin{gathered}
l_{x}=\sum_{j=1}^{\beta} S_{x j} \\
m_{x}=\frac{\sum_{j=1}^{\beta} S_{x j} f_{x j}}{\sum_{j=1}^{\beta} S_{x j}} \\
e_{x j}=\sum_{i=x}^{\infty} \sum_{y=j}^{\beta} S_{i y}^{\prime}
\end{gathered}
$$

The net reproductive rate $\left(R_{0}\right)$, the mean generation time $(\mathrm{T})$, the intrinsic rate of increase $\left(r_{m}\right)$, and the finite rate of increase $(\lambda)$ were also calculated as follows [27]:

$$
\begin{gathered}
R_{0}=\sum l_{x} m_{x} \\
T=\frac{\ln R_{0}}{r_{m}}
\end{gathered}
$$




$$
\begin{gathered}
\sum_{x=0}^{\infty} e^{-r_{m}(x+1)} l_{x} m_{x}=1 \\
\lambda=e^{r_{m}}
\end{gathered}
$$

\subsection{Statistical Analysis}

The raw life history data for $C$. malaccensis obtained for each of the temperature regimes were entered separately into a Microsoft Excel 2016 data sheet. One-way ANOVA was used to study the effect of temperature on the development time of immature stages and the longevity of $C$. malaccensis. The means, standard errors, and variances of the population parameters were estimated using the bootstrap technique [33-35] (10,000 samples), which is contained in the TWOSEX-MSChart program. Differences among different temperatures were compared using the Tukey-Kramer procedure. Excel 2016 was used to create $S_{x j}, f_{x 4}, l_{x}, m_{x}, l_{x} m_{x}$ and $e_{x y}$ curves.

\section{Results}

\subsection{Life History Study}

C. malaccensis females and males completed development from egg to adult emergence at constant 22 to $32{ }^{\circ} \mathrm{C}$ temperatures (Table 1 ). The egg incubation period of $C$. malaccensis ranged from 1.90 to $5.25 \mathrm{~d}$ for females, and from 1.80 to $5.43 \mathrm{~d}$ for males. The shortest developmental time for the egg stage was at $32{ }^{\circ} \mathrm{C}$ and the longest was at $22{ }^{\circ} \mathrm{C}$ in both females and males. The egg incubation duration and the larva duration of females were significantly longer at $22^{\circ} \mathrm{C}$ than at the other temperatures with similar results in males $(p<0.05)$. The nymph period was not significantly different $(p<0.05)$ at the five different temperatures, with the shortest developmental time occurring at $32{ }^{\circ} \mathrm{C}$ and the longest at $22^{\circ} \mathrm{C}$ in both females and males. The life history, both in females and males, exhibited a significant difference at $22{ }^{\circ} \mathrm{C}$ compared to the other temperatures $(p<0.05)$; it ranged from 11.10 to $27.50 \mathrm{~d}$ (females) and 8.80 to $22.71 \mathrm{~d}$ (males). The development time of male adults was shorter than females within the experimental temperature range and the development duration decreased with increased temperature.

Within the temperature range studied, the development time of females first increased and then decreased (Figure 2). Development time was $>50 \mathrm{~d}$ at $22-28{ }^{\circ} \mathrm{C}$, and longest $\left(66 \mathrm{~d}\right.$ ) at $28^{\circ} \mathrm{C}$. The development time of males decreased gradually in the range of $22-32{ }^{\circ} \mathrm{C}$, with a maximum of $46.71 \mathrm{~d}$ at $22{ }^{\circ} \mathrm{C}$. Based on the total duration, males developed more quickly than females at all temperatures.

These results showed that increasing the temperature generally shortened the development time of $C$. malaccensis. Considering the fecundity and adult period, $24-28^{\circ} \mathrm{C}$ was the ideal temperature range for reproduction and biological control use of $C$. malaccensis. 
Table 1. Development time of C. malaccensis reared at different temperatures under laboratory conditions $(\mathrm{M} \pm \mathrm{SD})(\mathrm{d})$

\begin{tabular}{|c|c|c|c|c|c|c|c|c|c|c|c|c|}
\hline \multirow{2}{*}{ Temperature $/{ }^{\circ} \mathrm{C}$} & \multicolumn{2}{|c|}{ Egg } & \multicolumn{2}{|c|}{ Larva } & \multicolumn{2}{|c|}{ Protonymph } & \multicolumn{2}{|c|}{ Deutonymph } & \multicolumn{2}{|c|}{ Life history } & \multicolumn{2}{|c|}{ Adult } \\
\hline & Female & Male & Female & Male & Female & Male & Female & Male & Female & Male & Female & Male \\
\hline 22 & $5.25 \pm 0.25 a$ & $5.43 \pm 0.20 \mathrm{a}$ & $9.75 \pm 0.48 a$ & $10.00 \pm 1.02 \mathrm{a}$ & $4.25 \pm 0.95 a$ & $5.29 \pm 0.61 \mathrm{a}$ & $5.25 \pm 0.95 a$ & - & $27.50 \pm 2.18 \mathrm{a}$ & $22.71 \pm 1.46 a$ & $54.00 \pm 9.75 a$ & $46.71 \pm 6.70 \mathrm{a}$ \\
\hline 24 & $3.00 \pm 0.00 \mathrm{~b}$ & $2.40 \pm 0.15 b$ & $4.30 \pm 0.33 b$ & $6.00 \pm 0.68 b$ & $4.70 \pm 0.33 a$ & $5.10 \pm 0.31 a$ & $5.30 \pm 0.33 a$ & - & $20.30 \pm 0.33 b$ & $15.90 \pm 0.73 b$ & $57.00 \pm 21.59 a$ & $40.80 \pm 5.69 \mathrm{ab}$ \\
\hline 28 & $2.30 \pm 0.29 \mathrm{~b}$ & $1.80 \pm 0.40 \mathrm{~b}$ & $4.30 \pm 0.18 \mathrm{~b}$ & $4.20 \pm 0.17 \mathrm{bc}$ & $3.30 \pm 0.18 a$ & $3.30 \pm 0.21 \mathrm{a}$ & $4.60 \pm 0.30 \mathrm{a}$ & - & $17.50 \pm 0.48 \mathrm{~b}$ & $11.30 \pm 0.33 c$ & $66.00 \pm 2.96 \mathrm{a}$ & $21.80 \pm 1.85 c$ \\
\hline 30 & $2.40 \pm 0.24 \mathrm{~b}$ & $2.00 \pm 0.58 b$ & $3.40 \pm 0.51 b$ & $3.00 \pm 0.58 c$ & $2.80 \pm 0.37 a$ & $3.33 \pm 0.33 a$ & $3.00 \pm 0.55 a$ & - & $14.60 \pm 0.40 \mathrm{~b}$ & $10.33 \pm 1.20 \mathrm{bc}$ & $16.00 \pm 3.97 \mathrm{~b}$ & $16.00 \pm 5.29 \mathrm{bc}$ \\
\hline 32 & $1.90 \pm 0.20 \mathrm{~b}$ & $1.80 \pm 0.15 b$ & $3.60 \pm 0.34 \mathrm{~b}$ & $3.60 \pm 0.18 c$ & $2.70 \pm 0.24 a$ & $2.40 \pm 0.18 a$ & $3.00 \pm 0.29 a$ & - & $11.10 \pm 0.39 \mathrm{~b}$ & $8.80 \pm 0.15 c$ & $17.60 \pm 1.58 b$ & $13.20 \pm 1.05 c$ \\
\hline
\end{tabular}

Note: Data in the table are represented as mean \pm SE. The means followed by different letters in the same columns are significantly different at the 0.05 level based on one-way ANOVA and Tukey's HSD multiple range test. 


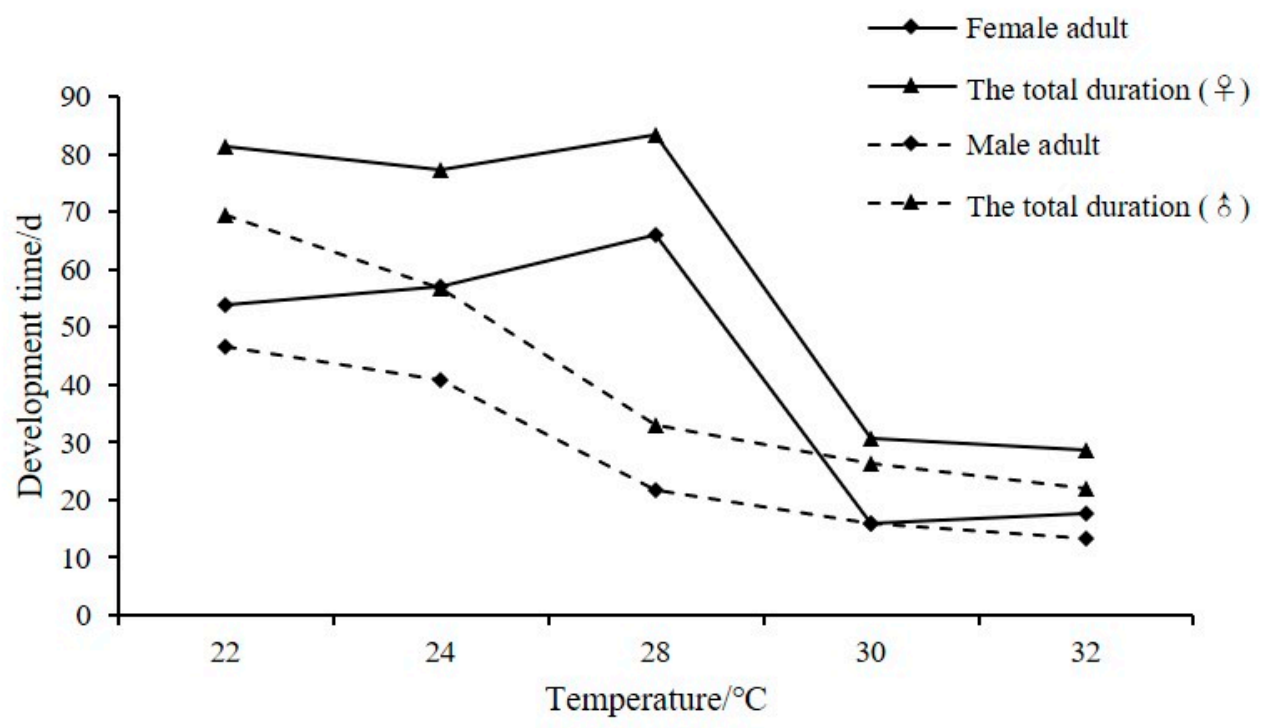

Figure 2. Relationship between temperature and the developmental time of $C$. malaccensis.

\subsection{Population Parameters}

Table 2 shows the population parameters of $C$. malaccensis, based on the two-sex life table theory and analysis technology, at $22,24,28,30$, and $32{ }^{\circ} \mathrm{C}$ with $75 \% \mathrm{RH}$. The mean generation time and life expectancy of $C$. malaccensis decreased gradually with an increased temperature. The lowest values at $32{ }^{\circ} \mathrm{C}$ were $12.49 \mathrm{~d}$ (mean generation time) and $22.15 \mathrm{~d}$ (life expectancy). The maximal $R_{0}(290.25)$ occurred at $28^{\circ} \mathrm{C}$. The $r_{m}$ of $\mathrm{C}$. malaccensis increased with increasing temperature. The minimum was 0.12 at $22{ }^{\circ} \mathrm{C}$, and the maximum was 1.4 at $32{ }^{\circ} \mathrm{C}$. $\lambda$ showed the same tendency and ranged from 1.12 to 1.40 .

Table 2. Population parameters of $C$. malaccensis at different temperatures.

\begin{tabular}{ccccccc}
\hline Temperature $/{ }^{\circ} \mathbf{C}$ & $\mathbf{T}$ & $\boldsymbol{R}_{0}$ & $\boldsymbol{r}_{\boldsymbol{m}}$ & $\boldsymbol{\lambda}$ & $\begin{array}{c}\text { Life } \\
\text { Expectancy }\end{array}$ \\
\hline 22 & $34.80 \pm 2.83 \mathrm{~cd}$ & $77.42 \pm 32.61 \mathrm{ab}$ & $0.12 \pm 0.02 \mathrm{~d}$ & $1.13 \pm 0.02 \mathrm{~d}$ & $216.20 \pm 54.03 \mathrm{a}$ & $65.80 \pm 5.75 \mathrm{c}$ \\
24 & $30.30 \pm 1.97 \mathrm{c}$ & $204.75 \pm 60.33 \mathrm{~b}$ & $0.18 \pm 0.02 \mathrm{c}$ & $1.19 \pm 0.02 \mathrm{c}$ & $526.15 \pm 6.85 \mathrm{~cd}$ & $59.51 \pm 4.48 \mathrm{c}$ \\
28 & $24.51 \pm 0.66 \mathrm{~b}$ & $290.25 \pm 70.58 \mathrm{~b}$ & $0.23 \pm 0.15 \mathrm{~b}$ & $1.26 \pm 0.19 \mathrm{~b}$ & $544.52 \pm 13.47 \mathrm{c}$ & $56.91 \pm 6.68 \mathrm{c}$ \\
30 & $14.37 \pm 1.31 \mathrm{a}$ & $50.28 \pm 15.79 \mathrm{a}$ & $0.27 \pm 0.03 \mathrm{ab}$ & $1.31 \pm 0.04 \mathrm{ab}$ & $93.41 \pm 17.66 \mathrm{~b}$ & $27.55 \pm 2.38 \mathrm{~b}$ \\
32 & $12.49 \pm 0.65 \mathrm{a}$ & $67.03 \pm 18.02 \mathrm{a}$ & $0.33 \pm 0.03 \mathrm{a}$ & $1.40 \pm 0.04 \mathrm{a}$ & $148.96 \pm 16.10 \mathrm{a}$ & $22.15 \pm 1.22 \mathrm{a}$ \\
\hline
\end{tabular}

Note: Data in the table are represented as mean \pm SE. The means followed by different letters in the same columns are significantly different at the 0.05 level based on one-way ANOVA and Tukey's HSD multiple range test. $R_{0}$ net reproductive rate, $\mathrm{T}$ mean generation time, $r_{m}$ intrinsic rate of increase, $\lambda$ the finite rate of increase.

\subsection{Life Table Analysis}

Because of the absence of deutonymphs in males, the nymphal stages were referred to as "nymph". Figure 3 shows age-stage-specific survival rates $\left(S_{x j}\right)$, which indicate the rate of individuals surviving to age $\mathrm{x}$ and stage $\mathrm{j}$. The $S_{x j}$ curves varied greatly at different temperatures and overlaps were observed in the $S_{x j}$ curves, which demonstrated the variable developmental rates among individuals. The eggs of $C$. malaccensis hatched at all of the temperatures, and the incubation time decreased significantly with an increased temperature. The mean generation time of $C$. malaccensis shortened with an increasing temperature, from $100 \mathrm{~d}$ at $22{ }^{\circ} \mathrm{C}$ to $31 \mathrm{~d}$ at $32{ }^{\circ} \mathrm{C}$. Mite survival was highest at $28^{\circ} \mathrm{C}$ and lowest at $32^{\circ} \mathrm{C}$. The results showed that there were overlapping generations in the growth and development of C. malaccensis. Excessively high temperature had adverse effects on the growth and development of C. malaccensis. 

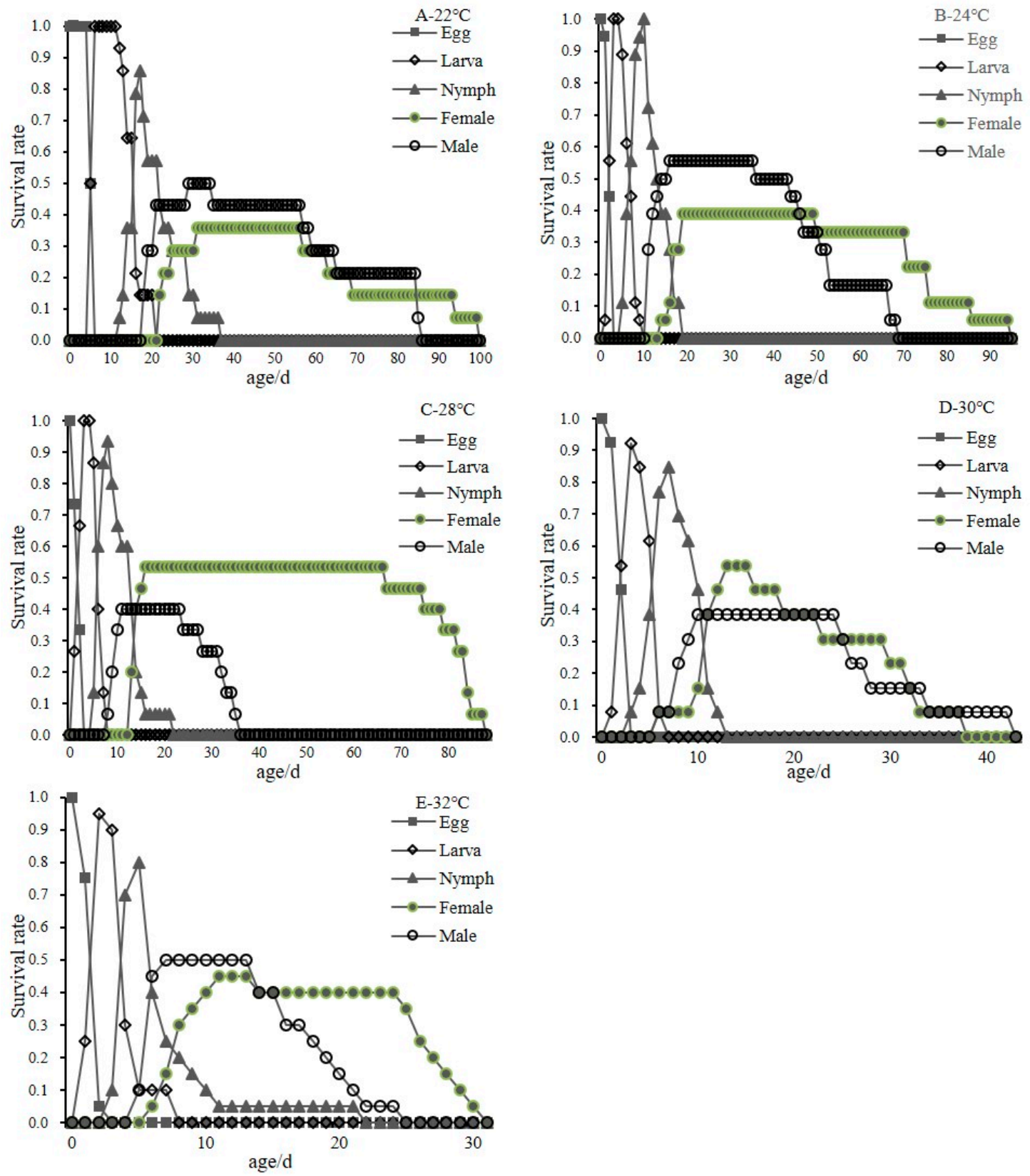

Figure 3. Age-stage specific survival rate $\left(S_{x j}\right)$ of $C$. malaccensis at different temperatures (A-E are 22, $24,28,30$ and $32{ }^{\circ} \mathrm{C}$, respectively).

Figure 4 summarizes the age-specific survival rate $\left(l_{x}\right)$, the age-specific fecundity $\left(m_{x}\right)$, the age-specific reproductive value $\left(l_{x} m_{x}\right)$, and the age-stage-specific fecundity $\left(f_{x 4}\right)$ of $C$. malaccensis at different temperatures. The age-specific survival rate $\left(l_{x}\right)$ simplified the survival of different development periods and did not consider differences among individuals. At $22{ }^{\circ} \mathrm{C}$, the age-specific survival rate $\left(l_{x}\right)$ of $C$. malaccensis showed a trend from 0 to $56 \mathrm{~d}$, and slowly decreased to $80 \%$. After $56 \mathrm{~d}$, the survival rate decreased rapidly from $80 \%$ to $0 \%$ (Figure $4 \mathrm{~A}$ ). At $24{ }^{\circ} \mathrm{C}$, the survival rate of C. malaccensis decreased slowly to $88 \%$ from 0 to 43 days and then rapidly decreased to $0 \%$ at the age of $95 \mathrm{~d}$ (Figure 4B). At $28{ }^{\circ} \mathrm{C}$, the age-specific survival rate decreased from $100 \%$ at $21 \mathrm{~d}$ to $80 \%$ at $31 \mathrm{~d}$. It then rapidly decreased to $40 \%$ at $75 \mathrm{~d}$ and $0 \%$ at $88 \mathrm{~d}$ (Figure $4 \mathrm{C}$ ). The age-specific survival rate curves of $30^{\circ} \mathrm{C}$ and $32{ }^{\circ} \mathrm{C}$ showed the same trend of steady decline during the early development stages and then rapid decline near the end of development (Figure 4D,E). 

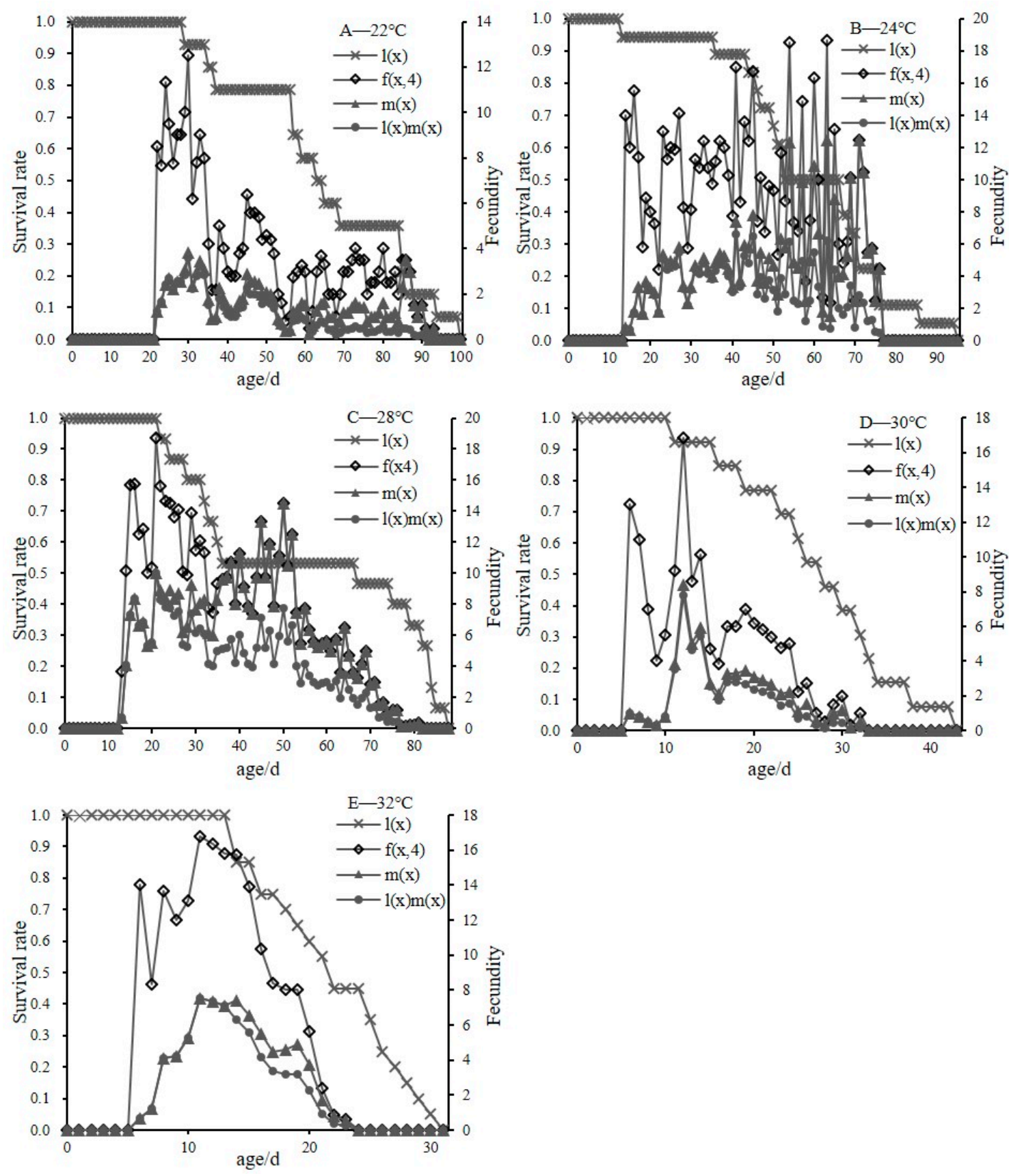

Figure 4. Age-specific survival rate $\left(l_{x}\right)$ fecundity $\left(m_{x}\right)$, maternity $\left(l_{x} m_{x}\right)$, and age-stage specific fecundity $\left(f_{x 4}\right)$ of $C$. malaccensis at different temperatures (A-E are $22,24,28,30$ and $32{ }^{\circ} \mathrm{C}$, respectively).

At the experimental temperatures, the $m_{x}$ curve had similar trends with the $f_{x 4}$ curve. At $22{ }^{\circ} \mathrm{C}$, the reproductive peaks of $f_{x 4}$ and $m_{x}$ occurred at the age of $30 \mathrm{~d}$ (Figure $4 \mathrm{~A}$ ), whereas the reproductive peaks occurred at $63 \mathrm{~d}$ at $24{ }^{\circ} \mathrm{C}$ (Figure $4 \mathrm{~B}$ ). At $28^{\circ} \mathrm{C}$, the peak of $f_{x 4}$ occurred at $21 \mathrm{~d}$, while the $m_{x}$ curve reached a reproductive peak at $50 \mathrm{~d}$ (Figure $4 \mathrm{C}$ ). The $f_{x 4}$ curves reached reproductive peaks early in the oviposition periods ( $16 \mathrm{~d}$ under $30^{\circ} \mathrm{C}$ and $11 \mathrm{~d}$ under $32^{\circ} \mathrm{C}$ ) (Figure $4 \mathrm{D}, \mathrm{E}$ ). The highest peak values of the $f_{x 4}$ and $m_{x}$ curves were at $28^{\circ} \mathrm{C}$, whereas the lowest values were at $22^{\circ} \mathrm{C}$, with peak values (high to low) at $28^{\circ} \mathrm{C}>24^{\circ} \mathrm{C}>30^{\circ} \mathrm{C}>32^{\circ} \mathrm{C}>22^{\circ} \mathrm{C}$. These results showed that the fecundity of $\mathrm{C}$. malaccensis was highest and the population growth was most rapid at $28^{\circ} \mathrm{C}$.

Figure 5 shows the age-stage specific life expectancy (the time that an individual of $C$. malaccensis of age $x$ and stage $j$ is expected to live) $\left(e_{x j}\right)$ of $C$. malaccensis at different temperatures. The $\left(e_{x j}\right)$ of 
C. malaccensis gradually decreased to 0 as age increased. At $22,24,28$, and $32{ }^{\circ} \mathrm{C}$, the $e_{x j}$ of female adults of $C$. malaccensis was higher than male adults during the whole development stage. At $30^{\circ} \mathrm{C}$, the $e_{x j}$ of males was lower than females except for the ages of 18-26 d, but higher than females in other development periods. The $e_{x j}$ curve decreased synchronously in both males and females at $30{ }^{\circ} \mathrm{C}$. The $e_{x j}$ at $28^{\circ} \mathrm{C}$ was slightly higher than the other temperatures. The $e_{x j}$ values of the initial reproducing $C$. malaccensis fed on $A$. siro were 65.79, 59.50, 56.93, 27.54, and 22.15 at 22, 24, 28, 30, and $32{ }^{\circ} \mathrm{C}$, respectively, which was also the average life expectancy of the individuals. The life expectancies of $\mathrm{C}$. malaccensis at 30 and $32{ }^{\circ} \mathrm{C}$ were about $50 \%$ of those at 22,24 , and $28{ }^{\circ} \mathrm{C}$. These results show that temperatures from 22 to $28^{\circ} \mathrm{C}$ were best for the growth and development of $\mathrm{C}$. malaccensis.
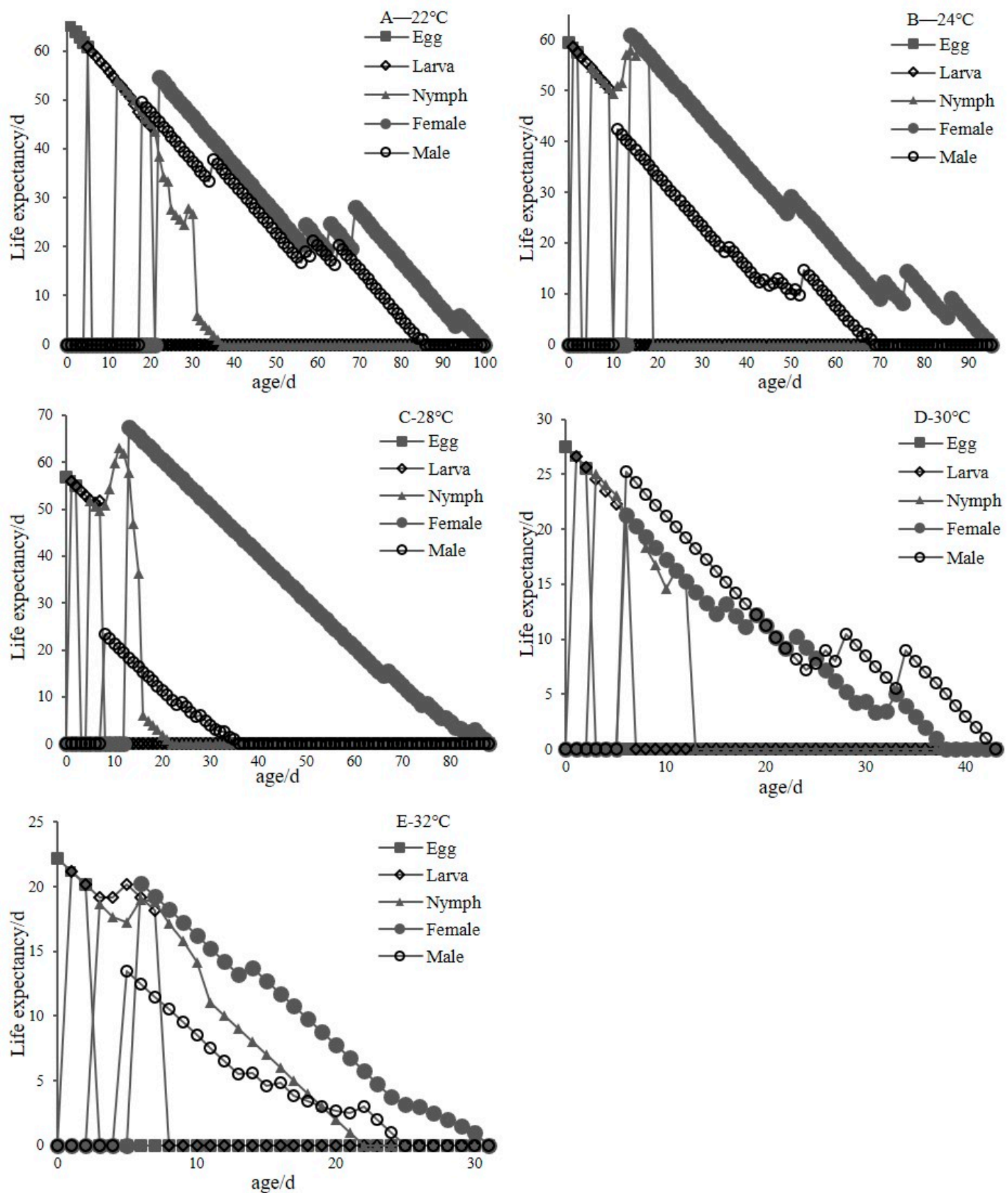

Figure 5. Age-stage specific life expectancy $\left(e_{x j}\right)$ of $C$. malaccensis at different temperatures (A-E are 22, $24,28,30$ and $32{ }^{\circ} \mathrm{C}$, respectively). 


\section{Discussion}

\subsection{Temperature}

Temperature is the most important environmental factor determining the development and reproduction of arthropods [12,36], and temperature affects the immature time, longevity, fecundity, and survival rates of arthropods [37,38].

The immature period development time decreased with increased temperature, which is consistent with other reports describing the effects of temperature on the growth and development of C. malaccensis $[13,15,21,22]$. The immature period development was slower compared to the findings of Palyvos and Emmanouel [15] at $25^{\circ} \mathrm{C}$ and $30{ }^{\circ} \mathrm{C}$, using Tyrophagus putrescentiae as prey. The life history was shorter than that reported by Saleh [21] when the growth temperature was $25^{\circ} \mathrm{C}$ and Aleuroglyphus ovatus was the prey. These differences may be due to the different prey used and may be related to prey quantity and nutrition quality provided by the prey. In addition, the efficiency of detecting and accessing can also cause differences in the results. Thus, it would be useful to study the effects of alternative prey for C. malaccensis. The predatory potential of cheyletidae mites has been reported, and mass rearing of cheyletidae mites in the laboratory has been described [18,39]. Many studies on the predator Cheyletus eruditus (Schrank) have been published [39-41]. Compared to C. eruditus, C. malaccensis is better adapted to higher temperatures, and therefore may have greater potential for biological control in warmer grain storage environments. As temperature increases, growth increases up to an optimum point after which higher temperatures begin to have negative effects on development; this observation is consistent with this study. When the temperature exceeded $28^{\circ} \mathrm{C}$, the adult lifespan decreased rapidly in both males and females. High temperature also had negative effects on the development of $C$. malaccensis. The environments of different ecological regions vary greatly in China. In actual application, it is best to make changes in predator numbers according to the different seasons and the different geographical area. To establish the predator population before a pest outbreak, and to ensure it will be sufficient for successful biological control, predatory mites need to be released prior to the development of the pest problem. In addition, it is advisable to make a safety evaluation of different predatory mites and to establish an optimum ratio of predators to their prey.

The adult is the most predatory stage of C. malaccensis [14]. We found that an optimal feeding temperature can shorten the development time of $C$. malaccensis. The development time was $>50 \mathrm{~d}$ during a temperature range of 22 to $28{ }^{\circ} \mathrm{C}$, with the longest development time being $66 \mathrm{~d}$ at $28{ }^{\circ} \mathrm{C}$. Considering fecundity and duration of the adult period, $24-28{ }^{\circ} \mathrm{C}$ is an ideal temperature range for reproduction and growth of $C$. malaccensis.

\subsection{Life Table}

The intrinsic rate of increase $\left(r_{m}\right)$ includes the population survival rate, duration of development, and fecundity. It is an important life table parameter and reflects the population growth capability at different temperatures [42]. Life table parameters can predict the future development trend of the population. Based on the two-sex life table theory and analysis technology, age-stage two-sex life tables of $C$. malaccensis fed on $A$. siro were constructed at temperatures ranging from 22 to $32{ }^{\circ} \mathrm{C}$ at $75 \%$ RH. The biological parameters, including growth, development, and fecundity, of C. malaccensis at different temperatures were compared and analyzed using the TWOSEX-MSChart.

The population growth ability of C. malaccensis was highest at temperatures ranging from 24 to $28{ }^{\circ} \mathrm{C}$. All individuals were included in the analysis, including both females and males. The $r_{m}$ of $C$. malaccensis increased with increasing temperature. This tendency is consistent with previous studies $[14,15,18]$. The $r_{m}$ and $\lambda$ of $C$. malaccensis were highest at $32{ }^{\circ} \mathrm{C}$, while $R_{0}$ and the single female fecundity of $C$. malaccensis were highest at $28^{\circ} \mathrm{C}$. However, the fecundity of $C$. malaccensis fed on $\mathrm{T}$. putrescentiae was highest at $25^{\circ} \mathrm{C}$ and $30{ }^{\circ} \mathrm{C}$ for virgin females, and the highest fecundity for previously mated females was at $30^{\circ} \mathrm{C}$ [15]. These differences may be related to different biotypes in different regions of the world. Filipponi [43] reported that some mite species may have different 
reproductive patterns in different geographic regions. Other possible causes of variation include the ambient temperatures and the prey species used to feed the mites. Before the 1980s, C. eruditus was reported to be the dominant species in China [44]. However, C. malaccensis is now reported to be the dominant predaceous mite species with the highest potential for biocontrol in grain depots in China [6-10]. In contrast, C. malaccensis was reported as the mite species having the lowest potential for biocontrol in the Czech Republic [5]. This discrepancy may be due to differences in climate, geographical environments, and population replacement.

Our data indicate that $C$. malaccensis can develop and reproduce well at temperatures ranging from 22 to $32{ }^{\circ} \mathrm{C}$. However, in life table studies, we cannot measure the growth potential of a population based on single parameters. It is thus necessary to conduct a comprehensive analysis of the growth and development parameters of the entire population. To predict the times and the number of releases for biological control, it is useful to understand the development rate, age differentiation, reproductive rate, and survival rate of $C$. malaccensis. Life tables can help us understand the comprehensive effects of various factors on the population growth of $C$. malaccensis. Traditional life tables have typically focused on the female population and lacked the contribution of males to population growth. This has limited their practical application. The stage differentiation and stage overlaps in development can be accurately described by using the age-stage, two-sex life table, whereas the traditional life table is incapable of accomplishing this. Under normal conditions, females make a higher contribution to the population and have a higher life expectancy and survival rates at all stages compared to males. Because of this, most current life table studies have focused on females $[45,46]$.

Male adults also contribute to predation and there were many differences between females and males. We found that the survival rate of male adults was higher than that of female adults at specific temperatures and specific ages. This indicated that male adults may have a higher survival rate than female adult mites at certain temperatures. More studies on males are needed to confirm these findings. This will be helpful for the establishment of populations in biological control programs and for high-temperature and low-temperature regimes in the artificial propagation of $C$. malaccensis. It is necessary to determine the long-term effects in consideration of the age-stage, two-sex life table. The comprehensive evaluation of a predatory natural enemy requires consideration of the basic parameters affecting its growth and development, reproduction, and population dynamics. More attention needs to be paid to predator-prey interactions under natural conditions. Increased knowledge of C. malaccensis biology will increase its utility as a biological control agent.

\section{Conclusions}

Age-stage, two-sex life tables of C. malaccensis, reared on Acarus siro were constructed at 22, $24,28,30$, and $32{ }^{\circ} \mathrm{C}, 75 \%$ relative humidity. Increasing temperature shortened the development time. The complete generation time of $C$. malaccensis ranged from $11.10 \mathrm{~d}$ to $27.50 \mathrm{~d}$. The optimum temperature for the growth and development of $C$. malaccensis was $28{ }^{\circ} \mathrm{C}$. Populations could increase rapidly, occurred the highest net reproductive rate $\left(R_{0}=290.25\right)$ and highest fecundity $(544.52)$ at this temperature. The values of age-specific fecundity (high to low) were $28^{\circ} \mathrm{C}>24{ }^{\circ} \mathrm{C}>30{ }^{\circ} \mathrm{C}>32{ }^{\circ} \mathrm{C}>$ $22{ }^{\circ} \mathrm{C}$. The result is useful for predicting its population dynamics, and guiding artificial breeding and delivery C. malaccensis to control the stored-product pests.

Author Contributions: Conceptualization, Y.C. and Y.W.; Formal analysis, W.S.; Funding acquisition, Y.C. and Y.W.; Methodology, Y.W.; Supervision, Y.W.; Validation, M.C., L.X., and Q.Y.; Writing-Original draft, W.S.; Writing-Review and editing, W.S., M.C., Y.C., and Y.W. All authors have read and agreed to the published version of the manuscript.

Funding: This research was funded by the Optional Research Project of the Academy of National Food and Strategic Reserves Administration (ZX1917-1 and ZX1917-2) and the National Key R\&D Program of China (2016YFD0401004-2).

Acknowledgments: Authors would like to thank Lu Liu and Peihuan He for the assistance provided on the statistical analysis. 
Conflicts of Interest: The authors declare no conflict of interest.

\section{References}

1. Shen, Z. The biology of stored mites-Cheyletus malaccensis. Grain Storage 1997, 5, 50-51.

2. Ling, P. Phylogenetic Status and Genetic Diversity of Cheyletus malaccensis Oudemans; Nanchang University: Nanchang, China, 2008; pp. 1-57.

3. Wafa, A.K.; Zaher, M.A.; Soliman, Z.R. Life history of the predator mite Acaropsis aegyptiaca Wafa \& Soliman (Acarina: Cheyletidae). Bull. Entomol. Soc. Egypt 1970, 54, 155-158.

4. Solomon, M.E. Experiments on predator-prey interactions of storage mites. Acarology 1969, 11, 484-503.

5. Lukáš, J.; Stejskal, V.; Jarošík, V.; Hubert, J.; Žd'árková, E. Differential natural performance of four Cheyletus predatory mite species in Czech grain stores. J. Stored Prod. Res. 2007, 43, 97-102. [CrossRef]

6. Li, X.; Li, G.; Hao, L. Investigation of stored grain mites in Henan Province. J. Zhengzhou Grain Coll. 1988, 4 , 64-69.

7. Tian, J.; Ren, Z.; Zhang, T. Preliminary report on the composition and occurrence of stored grain mites in Shanxi Province. Grain Process. 1988, 4, 1-4.

8. Chen, Q. A Preliminary report on the faunal investigation of the warehouse pests in Tibet Autonomous Region. J. Zhengzhou Grain Coll. 1990, 3, $29-41$.

9. Chen, Q. Investigation and Research on Storage Pests in China. Grain Sci. Technol. Econ. 1994, 5, 6-9.

10. Wu, G.; Zhen, W.; Lan, B.; Huang, P.; Yang, Z. Investigation of stored grain mites in Jiangxi Province. Grain Storage 1990, 4, 15-22.

11. Cebolla, R.; Pekár, S.; Hubert, J. Prey range of the predatory mite Cheyletus malaccensis (Acari: Cheyletidae) and its efficacy in the control of seven stored-product pests. Biol. Control 2009, 50, 1-6. [CrossRef]

12. Palyvos, N.E.; Emmanouel, N.G. Temperature-dependent development of the predatory mite Cheyletus malaccensis (Acari: Cheyletidae). Exp. Appl. Acarol. 2009, 47, 147-158. [CrossRef] [PubMed]

13. Summers, F.M.; Witt, R.L. Oviposition and Mating Tendencies of Cheyletus malaccensis (Acarina: Cheyletidae). Fla. Entomol. 1973, 56, 277-285. [CrossRef]

14. Liu, L. A Preliminary Study on the Growing Development and Predatory Ability of Cheyletus malaccensis (Oudemans); Henan University of Technology: Zhengzhou, China, 2018; pp. 1-69.

15. Palyvos, N.E.; Emmanouel, N.G. Reproduction, survival, and life table parameters of the predatory mite Cheyletus malaccensis (Acari: Cheyletidae) at various constant temperatures. Exp. Appl. Acarol. 2011, 54, 139-150. [CrossRef]

16. Li, Y. Population Regulation and Dispersion Mechanism of Neoseiulus barkeri (Hughes) (Acari: Phytoseiidae); Southwest University: Chongqing, China, 2017; pp. 1-154.

17. Volgin, V.I. Acarina of the family Cheyletidae of the world. Akad Nauk SSSR Zool Inst Keys Fauna USSR 1987, 101, 1-532.

18. Pekár, S.; Hubert, J. Assessing biological control of Acarus siro by Cheyletus malaccensis under laboratory conditions: Effect of temperatures and prey density. J. Stored Prod. Res. 2008, 44, 335-340. [CrossRef]

19. Cuthbertson, A.G.S. The Feeding Rate of Predatory Mites on Life Stages of Bemisia tabaci Mediterranean Species. Insects 2014, 5, 609-614. [CrossRef] [PubMed]

20. Sánchez-Ramos, I.; Álvarez-Alfageme, F.; Era, P.C. Development and survival of the cheese mites, Acarus farris and Tyrophagus neiswanderi (Acari: Acaridae), at constant temperatures and 90\% relative humidity. J. Stored Prod. Res. 2007, 43, 64-72. [CrossRef]

21. Saleh, S.M.; El-Helaly, M.S.; El-Gayar, F.H. Life history of the predatory mite Cheyletus malaccensis (Oudemans). Acarologia 1986, 1, 37-40.

22. Toldi, M.; Faleiro, D.C.C.; Silva, G.L.D.; Ferla, N.J. Life cycle of the predatory mite Cheyletus malaccensis (Acari: Cheyletidae) fed on Poultry Red Mite Dermanyssus gallinae (Acari: Dermanyssidae). Syst. Appl. Acarol. 2017, 9, 1422-1430. [CrossRef]

23. Liu, L.; Cao, Y.; He, P.; Sun, W.; Yu, Q.; Zhou, G.; Wu, Y. A preliminary study of growth and development of Cheyletus malaccensis (Oudemans) under different humidity conditions. J. Henan Univ. Technol. Nat. Sci. Ed. 2018, 5, 102-107.

24. Gao, S.; Yang, Z. Application of life table in pest biological control. Chin. J. Biol. Control 2015, 2, 256-263. 
25. Parker, R.P.A.S. On the Influence of Density of Population upon the Rate of Reproduction in Drosophila. Proc. Natl. Acad. Sci. USA 1922, 8, 212-219.

26. Smith, D.P.; Keyfitz, N. Life Tables for Natural Populations of Animals. Q. Rev. Biol. 1947, 4, $283-314$.

27. Chi, H.; Liu, H. Two new methods for the study of insect population ecology. Acad. Sin. 1985, 2, $225-240$.

28. Chi, H. Life-Table Analysis Incorporating Both Sexes and Variable Development Rates Among Individuals. Environ. Entomol. 1988, 1, 26-34. [CrossRef]

29. Chi, H.; Yang, T. Two-Sex Life Table and Predation Rate of Propylaea japonica Thunberg (Coleoptera: Coccinellidae) Fed on Myzus persicae (Sulzer) (Homoptera: Aphididae). Environ. Entomol. 2003, 2, 327-333. [CrossRef]

30. Chi, H. A Computer Program for the Age-Stage, Two-Sex Life Table Analysis; National Chung Hsing University: Taichung, Taiwan, 2018.

31. Tuan, S.; Lee, C.; Chi, H. Population and damage projection of Spodoptera litura (F.) on peanuts (Arachis hypogaea L.) under different conditions using the age-stage, two-sex life table. Pest Manag. Sci. 2014, 70, 805-813. [CrossRef]

32. Chi, H.; Su, H.Y. Age-stage, two-sex life tables of Aphidius gifuensis (Ashmead) (Hymenoptera: Braconidae) and its host Myzus persicae (Sulzer) (Homoptera: Aphididae) with mathematical proof of the relationship between female fecundity and the net reproductive rate. Environ. Entomol. 2006, 35, 10-21. [CrossRef]

33. Johnson, R.W. An Introduction to the Bootstrap. Teach. Stat. 1994, 23, 49-54. [CrossRef]

34. Huang, Y.; Chi, H. Life tables of Bactrocera cucurbitae (Diptera: Tephritidae): With an invalidation of the jackknife technique. J. Appl. Entomol. 2013, 137, 327-339. [CrossRef]

35. Huang, H.W.; Chi, H.; Smith, C.L. Linking demography and consumption of Henosepilachna vigintioctopunctata (Coleoptera: Coccinellidae) fed on Solanum photeinocarpum: With a new method to project the uncertainty of population growth and consumption. J. Econ. Entomol. 2018, 111, 1-9. [CrossRef] [PubMed]

36. Huang, J.; Liu, M.; Zhang, Y.; Kuang, Z.; Li, W.; Ge, C.; Li, Y.; Liu, H. Response to Multiple Stressors: Enhanced Tolerance of Neoseiulus barkeri Hughes (Acari: Phytoseiidae) to Heat and Desiccation Stress through Acclimation. Insects 2019, 10, 449. [CrossRef] [PubMed]

37. Hoffmann, A.A.; Rensen, J.G.S.; Loeschcke, V. Adaptation of Drosophila to temperature extremes: Bringing together quantitative and molecular approaches. J. Therm. Biol. 2003, 28, 175-216. [CrossRef]

38. Cui, X.; Wan, F.; Xie, M.; Liu, T. Effects of Heat Shock on Survival and Reproduction of Two Whitefly Species, Trialeurodes vaporariorum and Bemisia tabaci Biotype B. J. Insect Sci. 2008, 8, 1-10. [CrossRef]

39. Žd'árková, E. Mass rearing of the predator Cheyletus eruditus (Schrank) (Acarina: Cheyletidae) for biological control of acarid mites infesting stored products. Crop Prot. 1986, 5, 122-124. [CrossRef]

40. Pulpán, J.; Verner, P.H. Control of Tyroglyphoid mites in stored grain by the predatory mite Cheyletus eruditus (Schrank). Can. J. Zool. 1965, 43, 417-432. [CrossRef]

41. Žd'árková, E. Biological control of storage mites by Cheyletus eruditus. Integr. Pest Manag. Rev. 1998, 3, 111-116. [CrossRef]

42. Farhadi, R.; Allahyari, H.; Chi, H. Life table and predation capacity of Hippodamia variegata (Coleoptera: Coccinellidae) feeding on Aphis fabae (Hemiptera: Aphididae). Biol. Control 2011, 59, 83-89. [CrossRef]

43. Filipponi, A. Experimental taxonomy applied to the Macrochelidae (Acari: Mesotigmata). In Proceedings of the First International Congress of Acarology; Evans, G.O., Ed.; Acarologia: Paris, France, 1964; pp. 92-100.

44. Shen, Z. Preliminary notes of Chinese Cheyletida mites and the life history of Cheyletus malaccensis Ouds. (Acarina: Cheyletidae). Acta Entomol. Sin. 1975, 03, 316-324.

45. Wu, S.; Gao, Y.; Xu, X.; Wang, E.; Wang, Y.; Lei, Z. Evaluation of Stratiolaelaos scimitus and Neoseiulus barkeri for biological control of thrips on greenhouse cucumbers. Biocontrol. Sci. Technol. 2014, 24, 1110-1121. [CrossRef]

46. Stenseth, C. Effect of temperature and humidity on the development of Phytoseiulus persimilis and its ability to regulate populations of Tetranychus urticae (Acarina: Phytoseiidae. Tetranychidae). Entomophaga 1979, 24, 311-317. [CrossRef]

(C) 2020 by the authors. Licensee MDPI, Basel, Switzerland. This article is an open access article distributed under the terms and conditions of the Creative Commons Attribution (CC BY) license (http://creativecommons.org/licenses/by/4.0/). 